\title{
The Investigation of the Relationship between Online Games and Acquisition of Turkish Vocabulary ${ }^{1}$
}

\author{
Bilal Şimşek
}

Akdeniz University, Turkey, bilalonursimsek@gmail.com

Bekir Direkci

Akdeniz University, Turkey, bdirekci@gmail.com

\begin{abstract}
This study examines the relationship between online games and Turkish vocabulary acquisition. It adopted the sequential explanatory design of the mixed methods research. The quantitative data were collected through cluster sampling technique from 225 students studying in two secondary schools. The qualitative data were collected through the criterion sampling technique of the purposeful sampling methods from 20 participants. While vocabulary knowledge assessment form was used to collect quantitative data, a semi-structured interview form was used for the qualitative data. According to quantitative findings, whilst there was a significant difference between the scores in vocabulary knowledge test and the duration of the game, experience in playing the game, and time spent in watching broadcasts, there was not a significant difference between vocabulary scores and following League of Legends on media or social media. The experience of the participants in playing games, the weekly hours of playing games, and weekly hours spent watching broadcasts significantly predicts the scores in the vocabulary test. Whereas the qualitative findings revealed the relation of watching broadcasts and playing League of Legends to learn words of foreign origin with its reasons, there was not a significant relationship between following social media and acquisition expressions of foreign origin.
\end{abstract}

Keywords: Turkish education, vocabulary, vocabulary acquisition, online games, league of legends

\footnotetext{
${ }^{1}$ This study is a part of an MA thesis, which was conducted and defended by the first author and supervised by the second

Citation: Şimşek, B., \& Direkci, B. (2019). The Investigation of the Relationship between Online Games and Acquisition of Turkish Vocabulary. International Journal of Instruction, 12(3), 69-88. https://doi.org/10.29333/iji.2019.1235a
} 


\section{INTRODUCTION}

Vocabulary constitutes a whole that consists of all words, reduplications, idioms, proverbs, terms, formulaic language and formulaic expressions in a language. A lot of values such as the history of the society that speaks the language, material and spiritual culture, beliefs, perspective of the world, and their relationship with each other have contributed to the vocabulary of a language. In the context of raising future generations, it is important to enrich vocabulary knowledge of students both in terms of individual sense by developing their way of thinking and communication skills and in terms of cultural interchange of material and spiritual terms related to social values. The fact that a person is liable to external influences as a social entity affects the process of enriching students' vocabulary knowledge. Especially, the increasing effect of foreign languages in daily interaction negatively affects the vocabulary and the syntactical features of Turkish language (Akalın, 2003; Tosun, 2005; Özkan, 2008; Şuataman and Kalafat, 2012; Sir, 2013; Salman, 2015). The individuals often encounter the words of foreign origin and those words continue their existence in many places such as media, social media, billboards, and workplace names (Akalın, 2017). With the rapid development of technology, new areas have emerged to influence the language and no adequate research has been conducted on this subject yet. One of these domains is digital games. The emergence of online games with the spread of technology has brought the concept of digital games to a different dimension. An individual can connect to online games at any time and any place via the internet. While it is estimated that games are played 39 million hours a day in Turkey, our country ranks number one in the social game category with 38.4 minutes per a session of a game of a player in the world (Bilgi Toplumu Dairesi, 2015).

League of Legends emerges as the most played online computer game in Turkey (Teknolojioku, 2017) where approximately 30 million people are actively playing digital games (Özistek, 2017). League of Legends is a team-based competitive online game that combines elements of role-playing games and strategic features. Two teams consisting of five game characters (champions) fight on different maps and game modes with their own design and game plan in the game (League of Legends, 2018). In all maps, the fundamental need for winning the game is the harmony between the players, naturally intra-team communication. Therefore, the players play the game by communicating either through texting or using voice communication tools. With these features, the League of Legends drew the attention of millions of players and advertising companies. It also took the attention of advertisement companies that the players of League of Legends and the money spent on this sector have increased. A lot of brands (Coca-Cola, 2015; Nescafe, 2016; Ülker, 2016; Vodafone, 2017; THY, 2017; Vestel, 2017) have noticed that League of Legends was played by masses of people and they prepared advertisements aimed at these players. Additionally, it is noticeable that sports teams such as Beşiktaş, Galatasaray, Fenerbahçe ve Bursaspor participated in League of Legends Turkey Champions League that is held every year. Within this framework the director of Riot Games in Turkey Bora Koçyiğit (2017) explains that over 3 million registered users in Turkey play League of Legends that has approximately 100 million players all over the world.

International Journal of Instruction, July $2019 \bullet$ Vol.12, No.3 
There are several studies conducted in our country about online games reaching millions of players. One of the focus of these studies is the negative effects of online games. However, these studies generally examined online risks and the effects of the online game on violence and game addiction (Kaya, 2013; Demirtaş Madran and Ferligül Çakılc1, 2014; Dönmez, 2015). In other respects, there were studies which considered the online game as teaching aids and adapted them into the teaching process (Güneş 2010; Tüzün, 2006). In addition, when the related literature was reviewed, it was seen that digital and online games could be used in language teaching by including learners inside and outside the classroom, and it was found that they could be effective tools to improve the vocabulary knowledge of the students (Baltra, 1990; Peterson, 2010; Reinders, 2012). Similarly, Butler, Someya and Fukuhara (2014) investigated the effect of digital games on Iranian children's English vocabulary learning. As a result of the research, it was seen that using the SHAIEx digital game in English vocabulary teaching gave more meaningful results than traditional teaching. Online games offer a safe and effective learning space to support language teaching (Kongmee, Strachan, Montgomery \& Pickard, 2011). It is considered that online games, which appeal to huge masses by offering a global gaming space and intensively embody written and verbal communication have an indispensable effect on informal language use of people as well as being formally used for language teaching. While this effect will have positive aspects in second language acquisition, it may have negative aspects of using mother tongue. Although the Turkish curriculum have two special purposes such as "Ensuring Turkish to use consciously, correctly and carefully in accordance with the rules of speech and writing" and "With reference to what he/she read, listening or watched, ensuring them to have pleasure and conscious of language and to develop their thought and imagination worlds by enriching their vocabulary" (MONE,2018), individuals actively use words of foreign origin which they learnt through online games in their social environments. This case conflicts with the statements of the special purposes above. In addition, such a condition make will make difficult to transfer the outcomes " he/she uses Turkish versions of the words of foreign origin in his/her speeches" and " he/she uses Turkish versions of the words of foreign origin in his/her writings". In this context, it is seen as a prerequisite to determine how online games are related to Turkish vocabulary. When the relevant literature is reviewed, it is seen that there is not any study on the relationship between online games and vocabulary knowledge of people. The purpose of this research, which is conducted to contribute to the literature, is to examine the relationship between online games and Turkish vocabulary.

\section{METHOD}

\section{Research Design}

This study adopted the sequential explanatory design of the mixed methods research. The sequential explanatory design is a process in which quantitative data is collected and analysed first, and then qualitative data is used in order to build the collected data on a solid basis (Creswell, 2003). 


\section{Study Group}

The study group consisted of 255 students who were selected through the cluster sampling technique from two secondary schools in Konyaalt1, Antalya. While 124 participants were playing the game "League of Legends", 131 of them did not play it. In line with the research purposes, the variance of vocabulary knowledge test scores of the participants who played the game and those who did not play was compared (see Table 3 ) and other statistical procedures were carried out with the data collected from 124 participants who played the game. Descriptive statistics results of the participants are shown in Table 1 below.

Table 1

Descriptive Statistics for Players Who Play League of Legends

\begin{tabular}{llll}
\hline \multicolumn{1}{c}{ Variables } & Group & $\mathrm{N}$ & $\%$ \\
\hline Gender & Female & 11 & 8.9 \\
& Male & 113 & 91.1 \\
Class Level & 5th grade & 23 & 18.5 \\
& 6th grade & 11 & 8.9 \\
& 7th grade & 41 & 33.1 \\
Experience in the Game & 8th grade & 49 & 39.5 \\
& 1-3 Years & 81 & 65.3 \\
Weekly Time Spent on Playing the Game & 4-6 Years & 43 & 34.7 \\
& 1-17 hours & 111 & 89.5 \\
Following Media/Social Media related to the & 18-34 hours & 13 & 10.5 \\
game & Following & 82 & 66.1 \\
Viewing duration of broadcasts related to the & Not Following & 42 & 33.9 \\
game & Not watching at all & 19 & 15.3 \\
& 1-11 Hours & 89 & 71.8 \\
& 11-22 Hours & 16 & 12.9 \\
\hline
\end{tabular}

In order to examine the quantitative findings obtained during the study in depth, the participants who attended the quantitative data collection process and met the predefined criteria were selected through the criterion sampling method. The variables of Vocabulary Knowledge Assessment Form such as experience in the game, the cases of following the League of Legends in the media-social media and the League of Legends broadcasters were defined as the criteria and 20 participants who met all these criteria constituted the study group. Interviews were conducted in order to determine where and how participants learned the words of foreign origin and how they used them in the social environment.

\section{Data Collection Tools}

\section{Vocabulary Knowledge Assessment Form}

In the quantitative part of the study it was aimed to determine the relationship between the knowledge level of the participants who played League of Legends on words of foreign origin used during the game and other environments and experience in the game, the time spent on following the game on media/ social media and the hours of watching broadcasts related to this game. In line with this aim, the words of foreign (kill almak, 
flash atmak, boostlamak, feedlemek...) origin used in media/ social media and during the game by League of Legends broadcasters were placed in a vocabulary knowledge assessment form. A literature review related to the topic was conducted and two experts' opinions were taken to ensure the validity of the assessment form. The form was administered to eight secondary school students to check the clarity of the items in the form. There was a student from each grade level who was studying in two different secondary schools.

A pilot study was carried out to provide the reliability of the assessment form and KR20 reliability coefficient was determined. The analysis results are shown in Table 2.

Table 2

Statistics Results for Vocabulary Knowledge Assessment Form

\begin{tabular}{lllll}
\hline \multirow{2}{*}{$\mathrm{N}$} & $\begin{array}{l}\text { Mean of Item } \\
\text { Difficulty }(\mathrm{p})\end{array}$ & $\begin{array}{l}\text { Mean of Item } \\
\text { Discrimination (D) }\end{array}$ & $\begin{array}{l}\text { Mean of Standard } \\
\text { Deviation (sd) }\end{array}$ & \multirow{2}{*}{ KR-20 } \\
\hline 97 & 0,615 & 0,718 & 24,145 & 0,983 \\
\hline
\end{tabular}

It is expected that items in an assessment tool should have item difficulty values between .20 and .80 (approximately .50) and mean of item discrimination (D) should be higher than .30. Furthermore, it is deemed suitable for an assessment tool to have reliability coefficient higher than .70 (Büyüköztürk, 2005).

\section{Semi- Structured Interview Form}

During the interview process, a semi-structured interview form was used to collect detailed information knowledge about the topic. The form was developed by taking the quantitative analysis results into account. It was asked for expert's opinion and four experts evaluated it in terms of content validity.

\section{Data Analysis}

In the scope of the study, the normal distribution of data was checked using coefficients of skewness and kurtosis, and \pm 1 interspace was accepted as the cut-off score. The data showing a normal distribution were analysed using parametric statistical methods (independent samples t-test), and when the data was not normally distributed the data were analysed using non-parametric statistical methods (Mann Whitney U-test, Kruskal Wallis test). When the scores of vocabulary knowledge assessment test were investigated for multiple regression analysis, since the scores of skewness and kurtosis values were close to \pm 1 range, it was acknowledged that the data did not deviate much from normality values and it is distributed approximately normally. It was also observed that all VIF values were below 10. After it was determined that all assumptions were met, the analysis was conducted.

Participant interview forms were numbered from P1 to P20 in order to analyse the qualitative data systemically. The aim here is that the themes illustrated in the findings section are supported by participant's opinions and contribute to the validity of the study. 
The data were analysed through the content analysis technique which requires to piece together the data under the same category of themes and organize the themes and interpret them so that readers can easily comprehend them (Yıldırım and Şimşek, 2011). For the analysis of data by content analysis reliability formula suggested by Miles and Huberman (1994); that is, Reliability= Agreement / (Agreement + Disagreement) for coding reliability was used. The reliability score was calculated as \% 84 and the codes were accepted as reliable. The results were presented in a descriptive manner and explained by using direct excerpts within the framework of themes found.

\section{FINDINGS}

\section{Quantitative Findings}

124 participants who played the online game League of Legends and 131 participants who did not play the game took part in this study. First, the difference between the scores of participants who played the game and participants who did not play the game were checked to determine the role of the game League of Legends in the acquisition of words of foreign origin in vocabulary knowledge assessment form. Other analyses were carried out on participants who played the game.

Independent samples t-test was computed to analyse if the scores of vocabulary knowledge test of groups involved in the study vary significantly from each other according to the status of playing the game or not. The analysis results are shown in Table 3 .

Table 3

T-Test Results of the Participants According to the Status of Playing the Online Game

\begin{tabular}{llllllll}
\hline & Group & $\mathrm{N}$ & $\bar{X}$ & $\mathrm{~S}$ & $\mathrm{sd}$ & $\mathrm{t}$ & $\mathrm{p}$ \\
\hline \multirow{2}{*}{ Point } & Playing & 124 & 47.04 & 22.80 & \multirow{2}{*}{253} & \multirow{2}{*}{20.306} & \multirow{2}{*}{0.000} \\
& Not-playing & 131 & 3.06 & 9.44 & & & \\
\hline \multirow{*}{*}{$\mathrm{p}<0.05$} & & & & & & &
\end{tabular}

According to independent samples t-test results carried out to determine if each group of participants varied significantly from each other according to the status of playing the game in terms of vocabulary knowledge assessment test scores, it was found that the

scores of participants significantly different from each other $\left(t_{(253)}=20.306, \mathrm{p}=0.000\right)$. According to results, it was observed that the mean score of the participants who played the game ( $\overline{\mathrm{X}}=47.04)$ was higher than the mean score of the participants who did not play the game $(\overline{\mathrm{X}}=3.06)$. It can be said that playing the online game was influential in the acquisition of words of foreign origin in vocabulary knowledge assessment form.

Whether the scores of vocabulary knowledge assessment test varied according to following media/ social media platforms on the game was analysed by independent samples T-test. The analysis results are demonstrated in Table 4. 
Table 4

T-Test Results of Participants According to Vocabulary Knowledge Assessment Scores for the Following the Game on Media/ Social Media

\begin{tabular}{llllllll}
\hline & Group & $\mathrm{N}$ & $\bar{x}$ & $\mathrm{~S}$ & $\mathrm{sd}$ & $\mathrm{t}$ & $\mathrm{p}$ \\
\hline \multirow{2}{*}{ Point } & Following & 82 & 49.42 & 23.07 & \multirow{2}{*}{122} & \multirow{2}{*}{1.639} & \multirow{2}{*}{0.104} \\
\hline$* \mathrm{p}<0.05$ & Not Following & 42 & 42.38 & 21.79 & & &
\end{tabular}

According to results, it was found that the vocabulary knowledge assessment scores did not significantly differ according to the dimension of following the game on media/

social media $\left(t_{(122)}=1.639, \mathrm{p}=0.104\right)$.

Whether the scores of participants on vocabulary knowledge varied according to experience in playing the game is analysed by independent samples T-test and the results are illustrated in Table 5.

Table 5

T-Test Results for Vocabulary Knowledge Scores According to Experience in Playing the Game

\begin{tabular}{llllllll}
\hline & Group & $\mathrm{N}$ & $\bar{X}$ & $\mathrm{~S}$ & $\mathrm{sd}$ & $\mathrm{t}$ & $\mathrm{p}$ \\
\hline Point & 1-3 Year(s) & 81 & 40.14 & 22.12 & 122 & -5.059 & 0.000 \\
\hline * $<<0.05$ & 4-6 Years & 43 & 60.02 & 60.02 & 122 &
\end{tabular}

According to the results, it was found that there was a significant difference between the

scores of vocabulary knowledge and online-gaming experience $\left(t_{(122)}=-5.059\right.$, $\mathrm{p}=0.000$ ). The mean score of the participants who had four to six years of experience $(\overline{\mathrm{X}}=60.02)$ was higher than the mean score of the participants who had one to three years of experience $(\overline{\mathrm{x}}=40.14)$.

Mann-Whitney U Test was also applied to check if the vocabulary scores had any significant difference according to weekly time spent in playing the game, and test results are given in Table 6 .

Table 6

Mann-Whitney U Test Results of Vocabulary Scores According to Weekly Time Spent in Playing the Game

\begin{tabular}{llllll}
\hline & $\mathrm{N}$ & Mean Rank & Sum Rank & U & $\mathrm{p}$ \\
\hline $1-17$ hour(s) & 111 & 57.57 & 6319.500 & 174.500 & 0.000 \\
$18-34$ hours & 13 & 104.58 & 1359.50 & & \\
\hline${ }^{*} \mathrm{p}<0.05$ & & & &
\end{tabular}

$* \mathrm{p}<0.05$

According to the findings, it was observed that the scores of vocabulary assessment test had a significant difference in the dimension of weekly time spent playing the game 
$(\mathrm{U}=174.500, \mathrm{p}=0.000)$. When mean ranks are taken into consideration it can be argued that students who spent eighteen to thirty-four hours per week on playing the game knew more words of foreign origin than students who spent one to seventeen hours per week on playing the game.

Kruskal Wallis Test was applied in order to specify if there was a significant difference in participants' vocabulary assessment scores according to their status of following the broadcasts about the game. The test results are shown in Table 7.

Table 7

Kruskal Wallis Test Results for Scores of Vocabulary Assessment Test for the Dimension of Watching Broadcasts Related to the Game

\begin{tabular}{lllllll}
\hline & Status of Watching the Broadcasts & $\mathrm{N}$ & Mean Rank & $\mathrm{sd}$ & $\chi^{2}$ & $\mathrm{p}$ \\
\hline Point & Never & 19 & 27.34 & 2 & 29.89 & 0.000 \\
& $1-11$ Hour(s) & 89 & 64.55 & & & \\
& $12-22$ Hours & 16 & 92.84 & & & \\
\hline
\end{tabular}

*p $<0.05$

As it can be seen from Table 7, it can be said that there is a significant difference between test scores of the vocabulary test and the status of following broadcasts related

to the game $\left(\chi^{2}{ }_{s d=2, n=124)}=29.89, \mathrm{p}=.000\right)$. Binary combination of groups was examined by Mann Whitney U-test was used in order to specify the source of the difference, and it was observed that there were differences among all groups. When the mean rank of groups was taken into consideration, the participants who watched broadcasts from twelve to twenty-two hours had the highest scores, followed by participants who watched twelve to twenty-two hours, and the participants who did not watch broadcasts at all had the lowest mean rank. To determine the source of difference between groups Mann Whitney-U test was applied for every group. According to the results of the test, there is a significant difference between the groups who watched broadcasts never, and the participants who watched a broadcast one to eleven hours $(\mathrm{U}=310.50, \mathrm{p}=0.000)$. There was also a significant difference between the participants who never watched the broadcasts and who watched them twelve to twenty-four hours per week $(\mathrm{U}=19.00, \mathrm{p}=0.000)$. When the mean rank of the participants are taken into consideration, the scores of the participants who never watched broadcasts were lower than the scores of the participants who watched broadcasts one to eleven hours and twelve to twenty-four hours. Furthermore, there is also a significant difference between the participants who watched broadcasts some to eleven hours per week and twelve to twenty-four hours per week $(\mathrm{U}=359.50, \mathrm{p}=0.002)$. When the mean ranks are considered, the scores of participants who watched broadcasts twelve to twenty-two hours per week were higher than the participants who watched broadcasts one to eleven hours per week.

In order to specify if the experience of participants and weekly hours spent playing the game significantly predict the scores of vocabulary knowledge assessment test, multiple regression analysis was carried out. The findings of the analysis are demonstrated in Table 8. 
Table 8

Multiple Regression Analysis Results for the Prediction of Vocabulary Assessment Test Scores

\begin{tabular}{|c|c|c|c|c|c|c|c|}
\hline Variable & $\mathrm{B}$ & $\mathrm{Sd}$ & $\bar{\beta}$ & $\mathrm{T}$ & $\mathrm{p}$ & Bivariate $\mathrm{r}$ & Partial R \\
\hline Constant & -35.609 & 8.359 & - & -4.260 & 0.000 & - & - \\
\hline Gaming experience & 11.589 & 3.367 & 0.243 & 3.442 & 0.001 & 0.416 & 0.300 \\
\hline $\begin{array}{l}\text { Weekly Time Spent on } \\
\text { Gaming }\end{array}$ & 24.931 & 5.136 & 0.336 & 4.854 & 0.000 & 0.381 & 0.405 \\
\hline $\begin{array}{l}\text { Weekly Time Watching } \\
\text { Broadcasts }\end{array}$ & 19.990 & 2.927 & 0.467 & 6.831 & 0.000 & 0.502 & 0.529 \\
\hline$R=0.681$ & $\begin{array}{ll}R^{2} & \\
64 & 0.4\end{array}$ & & & & & & \\
\hline $\boldsymbol{F}_{(\mathbf{3 . 1 2 0 )}}=34.601$ & $\mathrm{p}=0.000$ & & & & & & \\
\hline
\end{tabular}

When the bivariate and partial correlations are examined between predictor variables and dependent variables, there is a positive moderate relationship between vocabulary test scores and online gaming experience $(\mathrm{r}=0.416)$, and when other variables are controlled the correlation coefficient between the variables is 0.405 . In addition, there is a positive moderate relationship between vocabulary test scores and weekly hours spent watching broadcasts $(\mathrm{r}=0.502)$. When the other variables are controlled, the correlation coefficient is found to be 0.529 .

In addition, there is also a positive significant difference between experience in online gaming, weekly time spent on playing the game, and weekly time spent on watching broadcasts and scores in vocabulary assessment task $\left(\mathrm{R}=0.681, R^{2}=0.464, \mathrm{p}=0.000\right)$. Online gaming experience, weekly time spent on playing the game, and weekly time spent on watching broadcasts predict approximately $68 \%$ of the total variance in vocabulary test scores. According to the standardized regression coefficients $(\beta)$, predictor variables' order of importance on participants scores of vocabulary assessment scores were weekly broadcast viewing time, experience in online gaming, weekly time spent on playing the game. Level of significance of regression coefficients' was investigated according to t-test results, and it was observed that weekly time watching broadcasts, experience in online-gaming, and weekly time spent playing the game were positive predictors for vocabulary assessment test scores of the participants. According to multiple regression analysis, a regression equation is given below:

Points $=-35.609+11.589 *($ Experience in Online Gaming $)+24.931 *($ Weekly Time Spent on Playing the Game)+19.990*(Weekly Time Spent on Watching Broadcasts)

\section{Qualitative Findings}

Findings in this section have been obtained by the analysis of interviews carried out to explain the quantitative data. As a result of the analysis participants' opinions are collected under four different theme categories. The vocabulary that appears in participants' views as a part of examples of different themes and words of foreign origin 
learned by means of the game League of Legends are shown in bold and italics. Themes and sub-themes that are formed as to the relationship between the online game League of Legends and Turkish vocabulary acquisition are demonstrated in Table 9.

Table 9

Participants' Views on the Relationship Between Online League of Legends Game and Turkish Vocabulary Acquisition

\begin{tabular}{lll}
\hline Themes & Sub-themes & $\mathrm{f}$ \\
\hline Media/ social media & Irrelevant & 12 \\
& Interesting & 8 \\
In Online Gaming Learning & & \\
& In-Game Communication & 10 \\
& Desire for Learning Foreign Languages & 8 \\
& Playing with a Foreign Language Option & 5 \\
& Playing on a foreign server & 4 \\
& & \\
Broadcaster-based learning & & 14 \\
& Turkish-speaking Broadcasters & 6 \\
& Foreign Language Speaking Broadcasters & 1 \\
& Irrelevant & 14 \\
& & 5 \\
& Circle of Friends & 4 \\
& Family Atmosphere & 1 \\
\hline & School Atmosphere & 92 \\
\hline
\end{tabular}

When the findings in Table 9 are examined, it is seen that participants' views centre on the theme in online game learning $(\mathrm{f}=27)$ when trying to explain the relationship between playing online League of Legends game and Turkish vocabulary acquisition. All of the participants could form a relationship between in-game learning theme and acquisition of word of foreign origin. When the frequency numbers are looked into social environment theme $(\mathrm{f}=24)$ comes second after the in-game learning theme. Most of the participants stressed that they learned some of the words of foreign origin appearing in the online game from their social environments or they have used these words in their social life before. When broadcaster-based learning theme $(f=21)$ is investigated, it is confirmed that participants formed an association with the learning of words of foreign origin and broadcasts. When the last theme constructed with participants' views, which was media/ social media $(\mathrm{f}=20)$, was analysed it was detected that most of the participants could not form an association between acquisition of words of foreign origin and media/ social media components.

Participants' Views on Acquisition of Words of Foreign Origin and Media/ Social Media Components

While most of the participants $(\mathrm{f}=12$ ) could not relate the acquisition of words of foreign origin to media/ social media factors, the others $(\mathrm{f}=8)$ found these factors to be 
interesting. When participants' views are examined, the participants who have an interest in media/ social media elements about League of Legends also do not give enough importance to language use related to these elements. Participants' views on media/ social media components about League of Legends are as the following:

"In fact, I do not really care about commercials. I already know the game. I play the game, and I like it. That is why I do not care about the commercials. ” (P8)

"I did not zap the commercial "Valley is Mine" ever. Normally I do not watch commercials. However, I never passed that commercial. I still remember the commercial. Valley is mine. Valley is mine. Have you heard what I said? I know about it. It was really good. It attracts my attention. It is because while most people do not understand it, you do like this. They tell me "What is up with this?" I tell them that I know about it. That is how it interests me. It appears nice to me." (P11)

Participants' Views on In-Game Learning and Acquisition of Words of Foreign Origin

It was specified that participants learned words of foreign origin by in-game communication $(\mathrm{f}=10)$, desire for learning foreign languages $(\mathrm{f}=8)$, playing with a foreign language option ( $\mathrm{f}=5$ ) and playing on a foreign server $(\mathrm{f}=4)$. The facts that these expressions seemed short, simple and logical and they were found to be more logical than their use in Turkish by participants were mentioned for the reasons why these words were learned and used. Participants' views about the acquisition of words of foreign words and in-game learning are as the following:

"Frankly, it seems illogical to me to say that stomach. Pardon me. It seems illogical to me to use the Turkish equivalent of the word "mid" when forming a sentence like "I threw teleportation to the mid corridor". It makes the sentence longer in vain. Also, you can shorten English terms; however, when you abbreviate Turkish terms you experience incomprehensibility of the message. That is why English terms we learn is better." (P4)

"In a sense, you learn English language better by this way, by playing such games. That is, I learned a lot of words from games." (P13)

"I play League of Legends with an English option. I both like its dubbing, and I like to understand English more easily." (P12)

"I learned this language by playing games. That is, I learned the words ignite, flash, teleport, exhaust. After all, I play the game. Besides, I played West, and I learned from there." (P19)

Participants' views on the acquisition of words of foreign origin and broadcaster-based learning

While most of the words of foreign origin were learned from Turkish-speaking broadcasters $(\mathrm{f}=14)$, there were also participants who learned these words by watching or listening to foreign language speaking broadcasters $(\mathrm{f}=6)$. Furthermore, a participant could not form a relationship between the acquisition of words of foreign origin and 
watching broadcasts. While it was emphasized that broadcasters who made Turkish broadcasts used words of foreign origin often, some reasons for watching foreign broadcasters were named as learning words of foreign origin and the fact that words of foreign origin seemed more appealing. Participants' views on learning words of foreign origin from foreign broadcasters were recounted as the following:

"Yes! Yes! Broadcasters use borrowed words more often in League of Legends. At first, I could not get it. I did not understand it at all. For instance, instead of the Turkish version of the word "ignite" they use the English word instead. It is helpful for me to watch foreign broadcasters because I learn from there better." (P13)

"The broadcasters I watch usually use English. That is, I watch foreign broadcasters. It is such as the one I watch on an online sports channel. I mean I watch the foreign version. Foreigners use English terms. Maybe that is why I got used to the English terms." (P7)

“No, I probably did not pay much attention, but I think they usually use Turkish.” (P12)

Participants' views on the acquisition and use of words of foreign origin

Most of the participants $(\mathrm{f}=14)$ emphasized that they learned or used words of foreign origin in a circle of friends. According to participants using these expressions in a friendly environment makes learning easier and a more genuine atmosphere is created. While most of the participants use words of foreign origin in the presence of their friends who know the game, the others use these words with all their friends. Besides, the participants expressed that they acquired or used words of foreign origin in a family atmosphere $(\mathrm{f}=5)$ and school environment $(\mathrm{f}=4)$. A participant could not form an association between the acquisition of foreign words and the social environment and pointed out that he or she does not use these words in his/her social life. Participants' views on the acquisition and use of words of foreign origin in social life have been exemplified as follows:

"I learn a lot more by talking to my friends who play League of Legends. For instance, a different thing like it is good when making jokes. For instance, the teacher asks a question. My friend could not answer it. Then, I tell my friends who play League of Legends that your Internet connection is cut off and you stay AFK. I say maybe ping timing is not functioning well. They laugh at this." (P11)

"At sometimes my friends and me are like friends, and I tilt her a little bit. I tell her what happened to you? Are you tilted? I tell her that she looks surprised at what I say to her. For instance, my mum tells me to come and have dinner. I tell that, "I am away from keyboard (AFK) mum." Some words are being used, but I cannot remember them now. These are the words used during some conversation specific to different situations." (P19) 
"Sometimes my friends sleep during class. I throw paper at their heads. I make a triangle folding the paper. I write there phrases such as $800 \mathrm{~K}$ Yasuo, I am AFK, and jungle report. I troll them." ( $\mathrm{P} 18)$

"No, I do not use them in my surroundings." (P12)

Qualitative findings attained during the research process have been analysed within the frame of four themes. At the end of the analysis, it has been detected that qualitative findings support quantitative findings.

\section{CONCLUSION AND DISCUSSION}

According to the findings of vocabulary assessment form, there is not a significant difference between the vocabulary scores of participants and following updates on League of Legends on media/ social media. The findings gained from interviews are also parallel to quantitative findings. While participants follow things related to League of Legends on media/ social media and tell that they are interested in them, they do not pay attention to language items used in these platforms. When the literature is reviewed, it is seen that words of foreign origin appear often on media/ social media elements (Akkoyunlu and Soylu, 2011; Şuataman and Kalafat, 2012; Karahisar, 2013; Gezgin and Silahsizoğlu, 2016). When posts about League of Legends on media/ social media are examined during the study, it is seen that words of foreign origin are used frequently similar to studies in previous literature. However, it is considered that participants learned words of foreign origin from different sources. Therefore, it is thought that they cannot form an association between acquisition of words of foreign origin and media/ social media elements.

When qualitative findings are taken into consideration, it is observed that there is a significant difference between participants who follow and posts about League of Legends on media/ social media in terms of acquisition of words of foreign origin. Besides, when the viewing duration of broadcasters increased, the level of acquisition of words of foreign origin increased as well. The qualitative findings of this study support the quantitative findings. Most of the participants learned words of foreign origin by watching or listening to broadcasters in a foreign language. The participants of the study follow the League of Legends broadcasts on the major broadcasting platform "Twitch TV". Twitch TV is a broadcasting platform where players can broadcast live and can be watched simultaneously by millions of people. Deng, Cuadrado, Tyson and Uhlig (2015) and Fisher (2014) found that the most watched and the most popular game on the Twitch TV was the League of Legends. While there are thousands of channels on Twitch TV broadcasting various games, and it is noteworthy that only the Riot Games (League of Legends) has been viewed over 1 billion (Twitch TV, 2018). The fact that thousands of people can simultaneously communicate in written and oral arouses interest in language as well. When studies in previous literature are reviewed, whereas broadcast viewers are defined as "a crowded bilingual play community", it has been detected that viewers developed a very special language for commenting on broadcasts and talking about the game episodes played (Olejniczak, 2015). Furthermore, it is 
observed that new words such as "Kappa" and "xPeked" are invented during broadcast conversation (Span, 2016). Levchenko (2010) indicated that according to studies a special language is used on broadcast platforms, and new words are created there; thereby, this finding supported Span (2016) and Olejniczak's (2015) results. When the findings of these studies are examined, it is seen that broadcast platform has a language specific to itself and a bilingual community is formed in these platforms. Also, new words appear and these expressions are preferred to have a rapid communication.

According to quantitative findings of this study, there is a significant difference between participants who play the League of Legends and those who do not play the game in terms of acquisition of words of foreign origin. Furthermore, experience in the game and increasing in time spent playing the game enhance the acquisition of words of foreign origin as well. Findings of the qualitative study support quantitative findings of the study. While most of the participants play the game with Turkish language option in the Turkish server, they learned words of foreign origin in online game communication. Additionally, some participants acquired words of foreign origin by using a Turkish server, while the others played the game in a Europe server with a foreign language option and acquired these words. In their study, Mora-Cantallops and Sicilia (2018) pointed out that young people spent thousands of hours playing the League of Legends. A website that supports this study reveals how long the League of Legends players spend in the game (Wasted on LOL, 2018). In addition, the League of Legends has become recognized as an e-sport due to its influence on young people and the size of its players (Agha, 2015; Pereira, Wilwert and Takase, 2016; Rosell Llorens, 2017).In this context, Lindemann (2016) examined the special language used in the League of Legends in the context of sports language. The researcher revealed the effect of English on the language used in the game by asserting that the terms of the game have emerged from America although the players of the League of Legends have different languages. Besides, it was emphasized that foreign words of foreign origin were preferred in order to communicate with non-German players and to use meaningful abbreviations. When other studies in the literature are examined, it is seen that individuals learn the words of foreign languages by playing digital games (Miller and Hegelheimer, 2006; Çetin, Sözcü \& Kinay, 2011).In their research, Rankin, Gold and Gooch (2006) concluded that the game called "EverQuest 2" has even the potential to improve students' English vocabulary learning and English speaking skills. When literature is reviewed, it is determined that participants playing League of Legends form complicated expressions by using a Turkish to English dictionary and use them during online game communication. Leppänen, Pitkänen-Huhta, Piirainen-Marsh, Nikula and Peuronen (2009) who carried out a similar study examined online conversation of a group of Finnish participants during Final Fantasy X game. At the end of the analysis, it was found that Finnish gamers created a mutual Finnish-English language during online gaming.

It is confirmed that they use these words in daily conversation besides the acquisition of these words by the participants in online gaming. While participants use these words of foreign origin most in friendly environments, the others prefer to use them in a family or 
school atmosphere. Learning words of foreign origin, using them in jokes and forming a friendly atmosphere are mentioned among reasons for the use of these words. Arslan (2017) established in a study that individuals who play computer games learn new words and grammatical structures from each other. The fact that students use the words of foreign origin they acquired in their social lives actively is not in agreement with the subjects that are "students use Turkish language consciously, accurately, and carefully according to written and oral rules", "they enrich their vocabulary size from what they read, heard, or watched, and they reach a level of enjoyment and consciousness in language while developing their emotions, ideas, and imagination" in curriculum for Turkish language teaching (Ministry of National Education in Turkey, 2018). In addition, it becomes harder to reach learning outcomes that are "in their daily speech they use the Turkish versions of the borrowed words that do not have a frequent use in our language" and "in their written works they use the Turkish versions of the borrowed words that do not have a frequent use in our language". The fact that words of foreign origin that are learned from online games becomes usable in daily life shows that they could not attain these learning outcomes in a full sense. Within this scope, suggestions of this study could be recounted as follows:

1. Researchers can conduct further studies to determine the effect of other online games on the acquisition of vocabulary.

2. Researchers can carry out studies to detect the special language used in online gaming broadcasts.

3. Turkish Language Society can conduct studies on the detection and controlling of words of foreign origin that start to appear in our language.

4. Students who play League of Legends can express events and situations they face in daily life by using words of foreign origin that they learned by playing the game. Teachers should pay attention to students' language use, take into consideration using Turkish only when talking to their students, and encourage them to use Turkish equivalents of the words of foreign origin.

5. Online games can be incorporated more into Turkish language curriculum, to texts in course books, and activities so that students who play online games will have a more conscious communication in these platforms and social life. 


\section{REFERENCES}

Agha, B. (2015). League of Legends: Players and Esports (Doctoral dissertation). McMaster University, Canada.

Aghlara, L., \& Tamjid, N. H. (2011). The effect of digital games on Iranian children's vocabulary retention in foreign language acquisition. Procedia-Social and Behavioral Sciences, 29, 552-560.

Akalın, Ş. H. (2003). Türkçenin teknik terim zenginliği [The richness of technical termsin Turkish]. Türk Dili Dergisi, 624, 767-778.

Akalın, Ş. H. (2017). Türkçenin güncel sorunları [Current problems of Turkish].

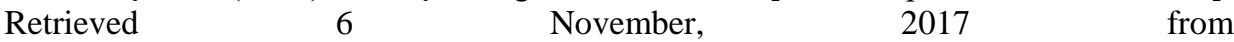
http://turkoloji.cu.edu.tr/DIL\%20SORUNLARI/02.php

Akkoyunlu, B., \& Soylu, M. Y. (2011). Sosyal iletișim ağları ve dilin yanlıș kullanımı üzerine nitel bir çalışma [A qualitative study on online social networks and language mistakes]. İlköğretim Online, 10(2), 441-453.

Arslan, H. (2017). Bilgisayar Oyunlartndan Gündelik Hayata Kültürel Bir Aktarlm Süreci Olarak Yabancı Dil Öğrenimi [Foreign language learning as a cultural transmission process from computer games to daily life] (Thesis). Ankara University, Ankara.

Baltra, A. (1990). Language learning through computer adventure games. Simulation \& Gaming, 21(4), 445-452.

Bilgi Toplumu Dairesi (2015), "2015-2018 Bilgi Toplumu Stratejisi ve Eylem Planı" [2015-2018 Information Society Strategy and Action Plan], T. C. Kalkınma Bakanlığı, Ankara.

Butler, Y. G., Someya, Y., \& Fukuhara, E. (2014). Online games for young learners' foreign language learning. Elt Journal, 68(3), 265-275.

Büyüköztürk, Ş. (2005). Sosyal Bilimler İçin Veri Analizi El Kitabı (5. Baskı) [Handbook of Data Analysis for Social Sciences (5 ${ }^{\text {th }}$ ed.)]. Ankara: Pegem Yayıncilık.

Coca-Cola. (2015). Coca-Cola zero. Retrieved 27 October, 2017 from https://tr.leagueoflegends.com/tr/news/riot-games/announcements/sampiyonlar-cocacola-zero-kutularini-susluyor

Creswell, J. W. (2003). Research design, qualitative, quantitative, and mixed methods approaches (2nd Edition). USA: Sage Publication.

Çetin, Y., Sözcü, O. F., \& Kınay, H. (2012). Sosyal ortamlardaki oyunlardan dolaylı yoldan yabancı dile ait kelime edinimi [Word acquisition of foreign language indirectly from social media games]. International Journal of Human Sciences, 9(2), 535-552. 
Demirtaş Madran, H. A., \& Ferligül Çakılcı, E. (2014). Çok oyunculu çevrimiçi video oyunu oynayan bireylerde video oyunu bağımlılı̆̆ı ve saldırganlık [The relationship between agression and online video game addiction: a study on massively multiplayer online video game players]. Anadolu Psikiyatri Dergisi, 15, 99-107.

Deng, J., Cuadrado, F., Tyson, G., \& Uhlig, S. (2015, December). Behind the game: Exploring the twitch streaming platform. In Network and Systems Support for Games (NetGames), 2015 International Workshop on (pp. 1-6). IEEE.

Dönmez, O. (2015). Sınıf öğretmeni adaylarının çocukların karşılaştı̆̆ çevrimiçi risklere yönelik algılarının çeşitli değişkenler açısından incelenmesi [Investigating preservice primary school teachers' perceived online risks for children] (Thesis). Anadolu University, Eskişehir.

Freezone 5'te 5 paketi [Freezone 5 in 5 packets]. Retrived 1 January, 2018 from http://www.vadibenim.com

Fisher, S. D. (2014). The Rise of eSports. League of Legends Article Series. Disponible en. Retrived 2 March, 2018 from http://www.foster.com/documents/foster-pepper-whitepaper/riseofesportswhitepaper-fosterpepper.pdf

Güneş, H. (2010). Geliştirilen çevrimiçi elektrogame oyununun ilköğretim 4. basamak bilişim teknolojileri dersi başarısına etkisi [The effect of online electrogame game on $4^{\text {th }}$ grade information technologies course in primary schools (Thesis). Bal1kesir University, Balıkesir.

Gezgin, D., \& Silahsızoğlu, E. (2016). Bilişim teknolojileri kullanımının Türkçeye etkileri [The impact of the use of information technologies on Turkish]. Turkish Online Journal of Qualitative Inquiry, 7(1), 28-46.

Karahisar, T. (2013). Dijital nesil, dijital iletişim ve dijitalleşen (!) Türkçe [Digital generation, digital communication and the digitalized (!) Turkish]. AJIT-e: Online Academic Journal of Information Technology, 4(12), 71-83.

Kaya, A. B. (2013). Çevrimiçi oyun bağımlılı̆̆ ölçeğinin geliştirilmesi: geçerlik ve güvenirlik çalışması [Development of online game addiction scale: a scale validity and reliability study] (Thesis). Gaziosmanpaşa University, Tokat.

Koçyiğit, B. (2017). Son dönemin yükselen trendi: E-spor [The rising trend of recent years: $\quad$ E-sport]. $\quad$ Retrived 8 November, 2017 from http://www.fanatik.com.tr/2017/03/17/ulker-league-of-legends-sampiyonluk-ligi-ninyeni-sponsoru-1283559.

Kongmee, I., Strachan, R., Montgomery, C., \& Pickard, A. (2011). Using massively multiplayer online role-playing games (MMORPGs) to support second language learning: Action research in the real and virtual world. In: 2nd Annual IVERG Conference: Immersive technologies for Learning: virtual implementation, real outcomes, 27-28 June 2011, Middlesborough, UK. 
League of Legends. (2018). Retrived 10 January, 2017 from https://tr.leagueoflegends.com/tr/

Leppänen, S., Pitkänen-Huhta, A., Piirainen-Marsh, A., Nikula, T., \& Peuronen, S. (2009). Young people's translocal new media uses: A multiperspective analysis of language choice and heteroglossia. Journal of Computer-mediated communication, 14(4), 1080-1107.

Levchenko, Y. G. S. (2010). Neologism in the lexical system of modern English: On the mass media material (Thesis). Luhansk Taras Shevchenko National University, Ukraine.

Lindemann, C. (2016). Sprachgebrauch in der Gamingszene. Eine Analyse der Sondersprache am Beispiel des MOBA League of Legends. Retrived 25 April, 2017 from https://www.grin.com/document/375836

Miles, M. B., \& Huberman, A. M. (1994). Qualitative data analysis: an expanded sourcebook. (2nd Edition). Calif.: SAGE Publications

Miller, M., \& Hegelheimer, V. (2006). The SIMs meet ESL: Incorporating authentic computer simulation games into the language classroom. International Journal of Interactive Technology and Smart Education, 3(4), 311-328.

Ministry of National Education in Turkey. (2018). Türkçe dersi ögretim programı (ilkokul ve ortaokul 1, 2, 3, 4, 5, 6, 7 ve 8. sinıflar) [Turkish Curriculum (primary and secondary schools 1, 2, 3, 4, 5, 6, 7 and 8th grades)]. Ankara: MEB.

Mora-Cantallops, M., \& Sicilia, M. A. (2018). MOBA Games: A literature review. Entertainment Computing, 26, 128-138.

Nescafe. (2016). Nescafé 3'ü 1 arada - oyuncu [Nescafé 3 in 1-player]. Retrived 17 August, 2017 from https://www.youtube.com/watch?v=Vf_GcedOSLU

Olejniczak, J. (2015). A linguistic study of language variety used on twitch. tv: descriptive and corpus-based approaches. Redefining Community in Intercultural Context, 1, 329-344.

Özistek, B. (2017). Türkiye pazarı küçük [Turkish market is not big]. Retrived 1 November, 2017 from https://www.evrensel.net/haber/324796/turkiyede-30-milyon-kisidijital-oyun-oynuyor

Özkan, M. (2008). Insan iletişim ve dil [Human, communication and language]. İstanbul: 3F Yayınevi.

Pereira, R., Wilwert, M. L., \& Takase, E. (2016). Contributions of Sport Psychology to the Competitive Gaming: An Experience Report with a Professional Team of League of Legends. International Journal of Applied Psychology, 6(2), 27-30. 
Peterson, M. (2010). Computerized games and simulations in computer-assisted language learning: A meta-analysis of research. Simulation \& Gaming, 41(1), 72-93.

Rankin, Y. A., Gold, R., \& Gooch, B. (2006, September). 3D role-playing games as language learning tools. In Eurographics (Education Papers) (pp. 33-38).

Reinders, H. (Ed.). (2012). Digital games in language learning and teaching. Basingstoke, England: Palgrave Macmillan.

Rosell Lorens, M. (2017). eSport gaming: the rise of a new sports practice. Sport, Ethics and Philosophy, 11(4), 464-476.

Salman, R. (2015). Yabancı kökenli kelimelerin yazımı sorunu ve bazı imla önerileri [The problem of writing foreign-rooted words and some spelling suggestions]. Bingöl Üniversitesi Sosyal Bilimler Enstitüsü Dergisi, 5(10), 73-78.

Sır, A. N. (2013). Türkçede batı kaynaklı kelimeler ve unsurlar sorunu [Western origin words and elements problem in Turkish]. The Journal of Academic Social Science Studies, 6(8), 969-982.

Span, F. B. (2016). Social Networks on Twitch. tv (Bachelor's thesis). Utrecht University, Netherlands.

Şuataman, Ö., \& Kalafat, Ş. (2012). Dil-zihin işleyişinin dil üzerindeki olumsuz etkisi: İnternet örneği [The negative effect of "language-mind relationship" on language: the internet]. Sosyal ve Beşeri Bilimler Dergisi, 4(2), 261-270.

Teknolojioku. (2017). Türkiye'de kaç kişi oyun oynuyor? [How many people play games in Turkey?]. Retrived 25 November, 2017 from http://www.teknolojioku.com/haber/turkiyede-kac-kisi-oyun-oynuyor-39920.html

Tosun, C. (2005). Dil zenginliği, yozlaşma ve Türkçe [Language richness, degeneration and Turkish]. Journal of Language and Linguistic Studies, 1(2), 136-154.

Türk Hava Yolları. (2017). Türk Hava Yolları, BAUSuperMassive'e sponsor oldu[Turkish Airlines sponsores BAUSuperMassive]. Retrived 26 March, 2017 from http://5mid.com/lol/turk-hava-yollari-bausupermassivee-sponsor-oldu

Tüzün, H. (2006). Eğitsel bilgisayar oyunları ve bir örnek: Quest Atlantis [Educational computer games and a case: Quest Atlantis] Hacettepe Üniversitesi Eğitim Fakültesi Dergisi, 30, 220-229.

Twitch TV. (2018). Riot Games. Retrived 8 Januarry, 2019 from https://www.twitch.tv/riotgames

Ülker. (2016). Mutluluk oynanır [Happiness is everywhere]. Retrived 28 May, 2017 from https://www.youtube.com/watch?v=5iynw90XguI 
Vestel. (2017). Vestel, League of Legends Şampiyonluk Ligi'nin partneri oldu [Vestel becomes the partner of the League of Legends Championship League]. Retrived 7 Januarry, 2018 from http://www.fanatik.com.tr/2017/04/12/vestel-league-of-legendssampiyonluk-ligi-nin-partneri-oldu-1288056

Wasted on LOL. (2018). How much time wasted on LOL? Retrived 16 April, 2018 from https://wol.gg/

Yıldırım, A., \& Şimşek, H. (2011). Sosyal bilimlerde nitel araştırma yöntemleri [Qualitative research methods in social sciences]. Ankara: Seçkin Yayıncıl1k. 